\title{
Birth order, aesthetic preference, and volunteering for an electric shock experiment
}

RUSSELL EISENMAN

UNIVERSITY OF GEORGIA

\begin{abstract}
Abstraet
Thirty-eight Ss, 19 first born, and 19 later born, were tested for anxiety, aesthetic preference, and susceptibility to threats of electric shock. Consistent with previous research, the first born Ss were more anxious (Taylor MAS), preferred simpler polygons, and were deterred from volunteering for an experiment which was said to contain strong electric shock. The threat of mild electric shock brought about less of an effect.
\end{abstract}

\section{Introduetion}

Studies on first born and only children date back at least as far as 1866 (Roberts \& Meyers, 1955). Adler presented his theoretical views on birth order in 1918 (Ansbacher \& Ansbacher, 1956), claiming that the first born is more conservative since he is dethroned by the second child from the position of the "little king" of the family. One of the more recent and comprehensive views on birth order has been put forth by Schachter (1959) who has found a stronger affiliative tendency in firstborn Ss. Schachter theorizes that first born children receive more inconsistent nurturance than later born children, which leads to dependency behavior in the form of affiliative responses. Schachter has shown that first born female Ss are made more anxious by threats of electric shock than later born females. Some empirical investigations which support Schachter are summarized in Schachter (1959), in Eisenman (1964), and elsewhere.

Since studies have often linked conservatism to the first born (e.g. Altus, 1963; Eisenman, 1964; Hall \& Barger, 1964) it was decided to employ polygon preferences in this investigation. The polygons used have previously discriminated creative art students from their less creative peers (Taylor \& Eisenman, 1964) and schizophrenics from non-schizophrenics (Eisenman, 1965). In both instances the less desirable group-less creative art students and schizophrenics-preferred less complexity. This preference for a relatively small amount of complexity has been shown to be correlated with conformity and conservatism (Barron, 1963).

The threats of electric shock have been shown to reveal differential birth order effects (Schachter, 1959; Staples \& Walters, 1961). It was felt desirable to see if the birth order effects would be prevalent in the present sample of Ss, and to note whether there was any relationship to aesthetic preference as revealed by the polygon preferences, which give a measure of S's preference for complexity or simplicity.

Based on previous research on birth order, the following hypotheses were advanced: (1) First born Ss would show greater preference for the simpler polygons.
(2) The introduction of anxiety via threats of electric shock would result in first borns volunteering less for an electric shock experiment than later born Ss.

\section{Method}

Subjects

Thirty-eight student nurses at Milledgeville State Hospital served as Ss. They were chosen so that half would be first born and half later born. Both first born and later born Ss averaged a family size of four children, including themselves. The mean difference in age between first born Ss and their next oldest sibling was $3 \mathrm{yr}$. Likewise, $3 \mathrm{yr}$. was the mean age difference between our later born Ss and their next oldest sibling. Stimulus material.

A photograph of 12 polygons was presented to each of the Ss. This photograph was of the polygons presented to Ss in the Taylor \& Eisenman study (1964), and was the same photograph employed by Eisenman (1965) in his study of schizophrenics. The polygons were three symmetrical forms taken from Birkhoff (1933) and nine constructed by connecting random points on a $100 \times 100$ grid, as described by Attneave \& Arnoult (1956). These nine asymmetrical polygons were composed of three with 4 points each; three with 12 points each; and three of 24 points. The three Birkhoff symmetrical polygons contained 4,8 , and 10 points. Complexity was defined by the number of points.

Procedure

Each nurse was presented the photograph of the polygons and asked to choose her three most preferred and three least preferred polygons. Nurses who asked what was meant by preference were told, "The ones you prefer the most. The ones you like best."

The nurses were also asked to participate in "a scientific experiment." Two levels of anxiety induction were used: mild and strong. In the mild condition Ss were told, "I would like for you to participate in a scientific experiment. In this experiment we will be studying the way people react to electric shock. However, the shock will be mild, and people do not find it painful." In the strong condition, Ss were told the same thing, except that in place of the last sentence was substituted "The shock will be painful, but the effects will not be permanent." Counterbalancing was employed for the presentation of the polygons and the request for experimental volunteers. However, Ss were always asked about participating in the mild shock experiment first, and then quizzed about their willingness to participate in the strong shock experiment. Ss were routinely asked to 
volunteer for both, even if they rejected the mild shock experiment.

To assess anxiety, the Taylor Manifest Anxiety Scale (1953) was administered to Ss after all experimental conditions had been imposed.

\section{Hesults}

The results for both the aesthetic preferences and for the amount of anxiety as revealed by the Taylor MAS were analyzed by the Mann-Whitney $U$ test, and in both cases first born Ss differed from later born Ss $(p<.05)$. First born Ss preferred simpler polygons, and were more anxious.

The results for the two shock threat conditions, strong and mild, were analyzed separately for first born and later born $\mathrm{Ss}$, and only among the firstborns was there a significant effect $\left(\chi^{2}=3.50, \mathrm{p}<.05,1 \mathrm{df}, \mathrm{McNemar}\right.$ test for the significance of changes, one-tailed).

Only among first born Ss in the strong shock threat condition did a significant number of nurses refuse to participate. Here only two of the 19 first born Ss agreed to volunteer (binomial $\mathrm{p}<.002$ ).

\section{Diseussion}

The results clearly support the two hypotheses: first born Ss were more likely to prefer simpler polygons, and were more likely to refuse to volunteer for the experiment with shock. This refusal to volunteer was pronounced only with the threat of strong shock. Also, first born Ss were more anxious than later born Ss. These results are consistent with the findings of Schachter (1959), with Staples \& Walters (1963) and with all those experimenters who claim that birth order can be an important variable.

It is interesting to note that while the first borns in this experiment preferred simpler polygons, the choices in general expressed less preference for complexity than was found in previous studies (Eisenman, 1965; Taylor \& Eisenman, 1964). This may mean that Ss in this experiment were notably conventional, conservative, or non-creative. If such a conclusion can be inferred it may explain the birth order effect: among fairly conservative Ss first borns are especially conservative.

This seems to be a problem connected with recent research on birth order: namely, that the research has concentrated upon showing conservatism to be associ- ated with being a first born child. Without disputing the results, it seems that work is needed on relatively creative or non-conventional Ss. Hall \& Barger (1964) found first born Ss to place emphasis upon seriousness and conservatism. Seriousness could just as well be associated with liberalism, but no liberalism factor emerged from Hall and Barger's factor analysis. Factor analysis or study of general student populations may leave out creativity or liberality, giving the specious impression that first born children are illiberal or conventional. They may be more likely to fall into these categories than their later born peers, but in light of the Ammons \& Ammons (1962) study which showed college students to be generally anti-intellectual, attempts should be made to study select groups of creative, liberal Ss to see if these populations also show greater conservatism for the first born.

\section{References}

Altus, W. D. The first born as a conservative: Adler revisited. Amer. Psychologist, 1963, 18, 356. (Abstract)

Ammons, C. H., \& Ammons, R. B. How to prevent genius: McCurdy revisited. Proc. Mont. Acad. Sci., 1962, 21, 145-152.

Ansbacher, H. L., \& Ansbacher, Rowena R. (Eds.) The individual psychology of Alfred Adler. New York: Basic Books, 1956.

Attneave, F., \& Arnoult, M. D. Methodological considerations in the quantitative study of shape and pattern in perception. Psychol. Bull., 1956, 53, 452-471.

Barron, F. Creativity and psychological health. New York: Van Nostrand, 1963.

Birkhoff, G. D. Aesthetic measure. Cambridge: Harvard University Press, 1933.

Eisenman, R. Birth order and artistic creativity. J. indiv. Psychol., 1964, 20, 183-185.

Eisenman, R. Aesthetic preferences of schizophrenics. Percept. mot. Skills, 1965, 20, 601-604.

Hall, E., \& Barger, B. Attitudinal structures of older and younger siblings. J. indiv. Psychol., 1964, 20, 59-68.

Roberts, B. H., \& Myers, J. K. Schizophrenia in the youngest male child of the lower middle class. Amer. J. Psychiat., 1955, 112, 129-134.

Schachter, S. The psychology of affiliation. Stanford: Stanford University Press, 1959.

Staples, F. R., \& Walters, R. H. Anxiety, birth order, and susceptibility to social influence. J. abnorm. soc. Psychol., 1961, 62, 716-719.

Taylor, Janet A. A personality scale of manifest anxiety. $J$. abnorm. soc. Psychol., 1953, 48, 285-290.

Taylor, R. E., \& Eisenman, R. Perception and production of complexity by creative art students. J. Psychol., 1964, 57, 239-242. 